\title{
Application of waste foundry sand (WFS) in civil construction.
}

\section{Gisleiva C. S. Ferreira (PQ), Luciene G. F. Domingues (PG), Wélida S. Sarro (IC), Gabriella Macedo (IC), Guilherme C. Silva (EM), Mileena Bianchi (EM), Marcella A. Georgini (EM), Stefhani A. Romero (EM).}

\begin{abstract}
Construction civil is one of the sectors that generate more solid waste, as well as there are several studies looking for solutions to best manage and reuse such material. The waste foundry sand (WFS) is a waste generated in large quantity by foundry industries. The application of this waste in construction is a way to reduce the environmental impact and natural resources exploration. On this wise, this research on such topics is to propose the WFS application in landfill and in pavements.
\end{abstract}

Key words: Landfill, Ultrasound, Compacted Soil, granulometric stabilization.

\section{Introduction}

A very viable alternative for the WFS is the functional application in other areas, as in civil construction, where studies indicate that this residue shows excellent results. A specific aim of this research was to propose a study of the physicochemical and mechanical characteristics of WFS samples and laterite soil mixtures with WFS. Therefore, the aim of this research was the granulometric stabilization of the laterite clay soil with WFS in order to apply it to cover intermediates layers of solid wastes in landfills as well as in paving.

\section{Results and Discussion}

For the landfill application of WFS it was carried out compaction tests on intermediate energy (NBR 7182: 1986) and permeability variable load (NBR 14545: 2000) (Figure 1). For the characterization of the mixtures of the soil+WFS, ultrasound tests and compressive strength were performed (NBR 5739:2007) according to figure 2.
Figure1. Permeameter.

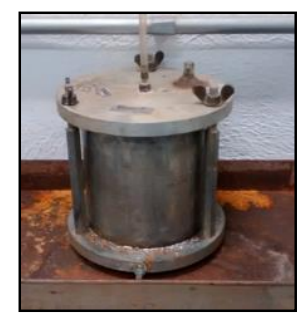

Figure 2. Ultrasound test.

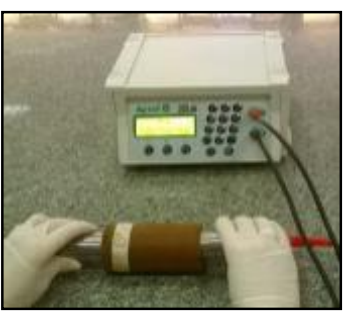

The average value obtained for the coefficient of permeability of the mixture $(\mathrm{K})$ was $5.2 \times 10^{-7} \mathrm{~cm} / \mathrm{s}$, which is ideal for landfills according to standards (USEPA 542-F-03-015, 2003; NBR 13896: 1997) for landfills execution. Figure 3 shows ultrasound results, where it is possible to observe the stabilization of the ultrasonic speed from 12 days of age.
Table 1 shows the compression strength results. For this test, the content of $60 \%$ WFS showed greater resistance compared to soil.

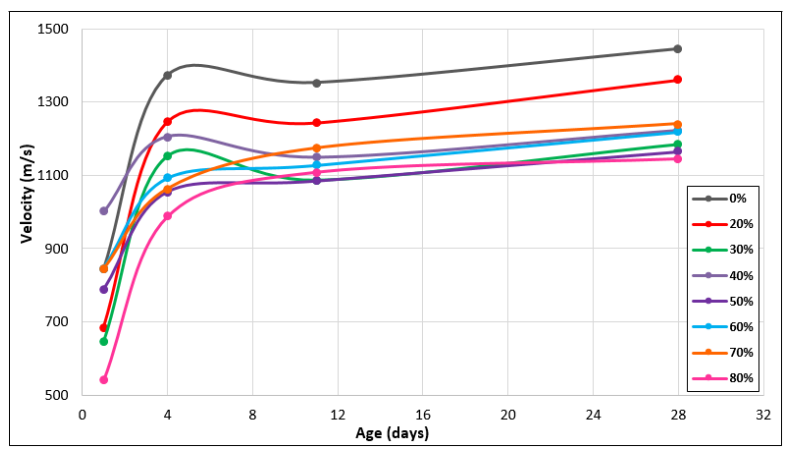

Figure 3. Results of the ultrasound test.

Table 1. Results of the Rc test.

\begin{tabular}{cccccc}
\hline Recipe & Soil & $20 \%$ & $40 \%$ & $60 \%$ & $80 \%$ \\
& & WFS & WFS & WFS & WFS \\
\hline Rc (MPa) & 0,75 & 0,70 & 0,72 & 0,86 & 0,44 \\
\hline
\end{tabular}

\section{Conclusions}

The research has shown the viability of the proposed use of WFS in landfills and paving up to the content of $60 \%$ WFS

\section{Acknowledgement}

The authors acknowledge the TUPY S.A Casting, FEMAQ Casting and UNICAMP.

\footnotetext{
ABNT (2000) NBR 14545: Solo - Determinação do coeficiente de permeabilidade de solos argilosos a carga variável. Associação Brasileira de Normas Técnicas, Rio de Janeiro.

${ }^{2}$ ABNT (1997) NBR 13896: Aterros de resíduos não perigosos Critérios para projeto, implantação e operação. Associação Brasileira de Normas Técnicas. Rio de Janeiro.

ABNT (1986) NBR 7182: Solo - Ensaio de compactação. Associação Brasileira de Normas Técnicas, Rio de Janeiro.

${ }^{4}$ ENVIRONMENTAL PROTECT AGENCY (USEPA) 542-F-03015. Evapotranspiration Landfill Cover Systems Fact Sheet. United States, September, 2003.
} 